\title{
Advocating a bottom-up approach in the teaching of feedback skills to medical students [Letter]
}

This article was published in the following Dove Press journal:

Advances in Medical Education and Practice

\author{
Silvia Allikmets' \\ Megan Catherine Schwarz ${ }^{2}$ \\ 'GKT School of Medical Education, King's \\ College London, London, UK; ${ }^{2}$ Icahn \\ School of Medicine, Mount Sinai \\ Oncological Sciences, New York, \\ NY, USA
}

\section{Dear editor}

Jamshidian et $\mathrm{al}^{1}$ discuss medical teachers' opinions regarding sources, methods, content, and presentation of feedback. We agree that feedback provision in medical education is beneficial for personal and professional growth, but that it can be relatively poor in quality, particularly regarding "authenticity of data sources," "data gathering methods," and "choosing an appropriate feedback presenter."1

We suggest that the lack of adequate feedback provision stems from medical school, where feedback is passively incorporated into students' learning via surveys and questionnaires, and techniques of providing feedback are often not explicitly addressed. ${ }^{2}$ To strengthen quality and authenticity of student feedback, these techniques should form a core component of medical education curricula. Jamshidian et $\mathrm{al}^{1}$ propose a feedback cycle offering a top-down approach to improving feedback provision, where recipients use feedback to adjust their behaviors. We suggest this should be used in conjunction with a bottom-up approach, where effective feedback provision techniques are formally taught early in education.

Additionally, feedback can be influenced by the status of the feedback provider. ${ }^{1}$ The authors mention that the most important criterion for the feedback provider was their "acceptance" by the recipient. The researchers" interviews revealed that a "competent clinical teacher," ie, a medical education expert, was the preferred feedback provider. However, this is incongruous with another result of their study, which identified students as the best source of feedback. We propose that formally teaching students how to deliver and provide feedback may help change the way in which student feedback is being perceived, by giving students the same authority as medical education experts. Instead of using a model that focuses on interactions between providers and recipients, students should be taught simple, structured frameworks on giving feedback. ${ }^{3}$

Furthermore, the application of emotional intelligence, ie, techniques and insights that help humans perceive their own and others' emotions, in teaching has led to improvement in clinical teachers' performances. ${ }^{4}$ Application of emotional intelligence could also avoid "negative emotional reactions such as denial and defense," experienced by some of the teachers in Jamshidian et al's study, ${ }^{1}$ and allow clinical teachers to reflect on feedback content objectively.
Correspondence: Silvia Allikmets GKT School of Medical Education, King's College London, Great Maze Pond, SEI IUL London, UK

Email silvia.allikmets@kcl.ac.uk 
The delivery of additional feedback using qualitative analysis has also improved the level of acceptance of feedback in medical students. ${ }^{5}$ Such tailoring and personalization of feedback to the recipients' traits may reduce the likelihood of emotional volatility, create a positive environment, and strengthen the quality of feedback and mutual respect and understanding between provider and recipient, to increase learning and improve patient care.

In conclusion, we believe students should become medical education experts through rigorous feedback training, which should emphasize a personalized approach for a positive reception. As doctors begin receiving feedback in medical school, it is the university's duty to assume responsibility for such training. Given the paucity of literature on this subject, the first step to integrating active feedback teaching would be to assess the effect of interventions that improve the quality of providing and receiving feedback.

\section{Disclosure}

The authors report no conflicts of interest in this communication.

\section{References}

1. Jamshidian S, Haghani F, Yamani N, Sabri MR. Provision of feedback to medical teachers on their educational performance: perspectives of internal medicine teachers. Adv Med Educ Pract. 2019;10:85-94. doi:10.2147/AMEP.S184178

2. Kruidering-Hall M, O'Sullivan PS, Chou CL. Teaching feedback to first-year medical students: retention and accuracy of student self-assessment. J Gen Intern Med. 2009;24(6):721-726. doi:10.1007/ s11606-009-0983-z

3. Kritek PA. Strategies for effective feedback. Ann Am Thorac Soc. 2015;12(4):557-560. doi:10.1513/AnnalsATS.201411-524FR

4. Omid A, Haghani F, Adibi P. Clinical teaching with emotional intelligence: a teaching toolbox. J Res Med Sci. 2016;21:27. doi:10.4103/ 1735-1995.181983

5. Uhm S, Lee GH, Jin JK, et al. Impact of tailored feedback in assessment of communication skills for medical students. Med Educ Online. 2015;20:28453. eCollection 2015. doi:10.3402/meo.v20.28453

Dove Medical Press encourages responsible, free and frank academic debate. The content of the Advances in Medical Education and Practice 'letters to the editor' section does not necessarily represent the views of Dove Medical Press, its officers, agents, employees, related entities or the Advances in Medical Education and Practice editors. While all reasonable steps have been taken to confirm the content of each letter, Dove Medical Press accepts no liability in respect of the content of any letter, nor is it responsible for the content and accuracy of any letter to the editor.

\section{Publish your work in this journal}

Advances in Medical Education and Practice is an international, peerreviewed, open access journal that aims to present and publish research on Medical Education covering medical, dental, nursing and allied health care professional education. The journal covers undergraduate education, postgraduate training and continuing medical education including emerging trends and innovative models linking education, research, and health care services. The manuscript management system is completely online and includes a very quick and fair peer-review system. Visit http://www.dovepress.com/testimonials.php to read real quotes from published authors. 